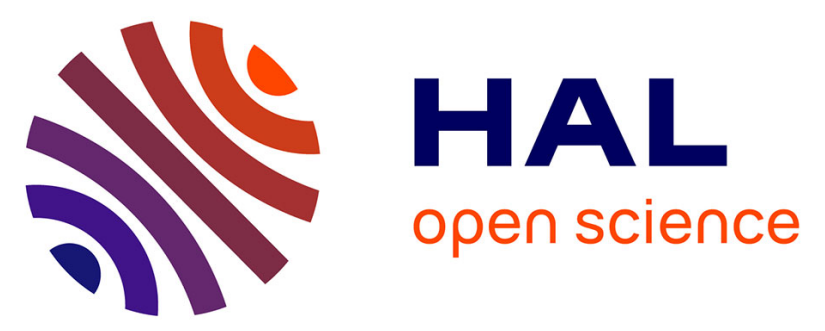

\title{
Spatio-temporal patterns of fish assemblages in a large regulated alluvial river
}

R. Rifflart, G. Carrel, Y. Le Coarer, B. Nguyen The Fontez

\section{To cite this version:}

R. Rifflart, G. Carrel, Y. Le Coarer, B. Nguyen The Fontez. Spatio-temporal patterns of fish assemblages in a large regulated alluvial river. Freshwater Biology, 2009, 54, p. 1544 - p. 1559. 10.1111/j.1365-2427.2009.02200.x . hal-00653265

\section{HAL Id: hal-00653265 https://hal.science/hal-00653265}

Submitted on 19 Dec 2011

HAL is a multi-disciplinary open access archive for the deposit and dissemination of scientific research documents, whether they are published or not. The documents may come from teaching and research institutions in France or abroad, or from public or private research centers.
L'archive ouverte pluridisciplinaire HAL, est destinée au dépôt et à la diffusion de documents scientifiques de niveau recherche, publiés ou non, émanant des établissements d'enseignement et de recherche français ou étrangers, des laboratoires publics ou privés. 


\title{
Spatio-temporal patterns of fish assemblages in a large regulated alluvial river. Freshwater Biology (2009), 54, 1544-1559
}

\author{
RENAUD RIFFLART *†, GEORGES CARREL*, YANN LE COARER* AND BENEDICTE \\ NGUYEN THE FONTEZ $\dagger$ \\ * Cemagref, UR HYAX, 13182 Aix-en-Provence, France. \\ † Université de Provence, UMR IMEP 6116, 13331 Marseille, France.
}

Correspondence: Renaud Rifflart, Cemagref, UR HYAX, 3275 Route de Cézanne, CS 40061, 13182 Aix-en-Provence cedex 5, France.

E-mail: renaud.rifflart@cemagref.fr

Key words: Fish; riverine habitat assessment; gravel-bed river; instream flow; GIS; Partial Least Square regression.

(Manuscript accepted 20 October 2008)

Author Posting. @ Renaud RIFFLART, Georges CARREL, Yann LE COARER AND Benedicte NGUYEN THE FONTEZ $\{2009\}$ This is the author's version of the work. It is

posted here for personal use, not for redistribution. The definitive version was published in Freshwater Biology, 54, 1544-1559 and is available at www.blackwell-synergy.com

http://dx.doi.org/10.1111/j.1365-2427.2009.02200.x 
Précisions: Dans la version publiée de l'article, trois espèces avaient été nommées sous leur ancienne dénomination scientifique : le chevaine (Leuciscus cephalus devenu Telestes cephalus), le toxostome (Chondrostoma toxostoma devenu Parachondrostoma toxostoma) et le blageon (Leuciscus souffia devenu Telestes souffia). 


\section{SUMMARY}

1. The River Durance, the last alpine tributary of the River Rhône, is a large, braided alluvial hydrosystem. Following large-scale regulation, flow downstream of the SerrePonçon dam has been maintained at 1/40th of previous annual mean discharge. To assess the effects of historical disturbances, fish assemblages and habitat use were analysed during five summers in a representative reach of the middle Durance.

2. Habitat availability and use were assessed with a multi-scale approach including the variables water depth, current velocity, roughness height of substratum, amount of woody debris and lateral/longitudinal location. Eighteen fish species were sampled by electrofishing in 289 habitat sample units.

3. Partial Least Square (PLS) regression showed that taxa were mainly distributed according to relationships between their total length and water depth/velocity variables. Fish assemblage composition was also related to roughness height as well as distance from the bank or to the nearest large woody debris. However, PLS regression revealed no significant differences in habitat selection between two periods of varying hydromorphological stability.

4. Fish distribution patterns and density were related to proximity to the bank and cover, indicating that local scale variables need to be considered in conservation and restoration programmes. 


\section{INTRODUCTION}

Natural disturbances such as floods or droughts are integral components of most freshwater ecosystems, and consequently organisms have evolved traits that enable them to survive, exploit and even depend on many kinds of disturbances (Townsend \& Hildrew, 1994; Bunn \& Arthington, 2002; Lytle \& Poff, 2004). For example, fish can move to refuge areas during spates, avoid hostile conditions by spawning after floods and protect their eggs by excavating deep nests in gravel bottoms (Lytle \& Poff, 2004). However, anthropogenic activities such as the regulation of rivers for hydropower often result in loss or modification of freshwater habitats (e.g. Nilsson et al., 2005), by changing river connectivity (Aarts, Van Den Brink \& Nienhuis, 2004; Hirzinger et al., 2004), altering exchange processes (Brunke \& Gonser, 1997) and fragmenting populations (Corbacho \& Sanchez, 2001). Although fishes are primarily affected by alterations in hydromorphology (Ormerod, 2003), separating the effects of flow regulation from other anthropogenic impacts on the floodplain, such as extraction of gravel, water abstraction and pollution, has proven to be difficult.

The riverscape is a complex and heterogeneous system including lateral floodplain water bodies connected to the main channel. This lateral connectivity is frequently used by riverine fishes as seasonal habitat and plays a functional role as spawning or nursery grounds. Habitat disturbances affect fish life-histories, survival, reproductive success and ultimately population growth rate (Copp, 1989; Molls, 1999; Borcherding et al., 2002; Dunham \& Rieman, 1999). Although these impacts are well known, fish community responses are not well understood (Nilsson et al., 2005). Disturbed wetlands have less species diversity (Chipps, Perry \& Perry, 1994), and invasion of exotic and fugitive species is facilitated by habitat alterations (Meffe, 1984; Moyle \& Light, 1996). Understanding the links between fish fitness and flow regimes 
or other habitat variables is important for an effective watercourse management (Lytle \& Poff, 2004).

In classical fish habitat studies, current velocity, water depth and substratum type are often used to explain spatial patterns and to calibrate predictive models (Gorman \& Karr, 1978; Bovee, 1982). However, recent studies have shown that these variables alone are not adequate to understand and predict fish responses (Brosse \& Lek, 2000; Mugodo et al., 2006). For instance, in complex hydrosystems, like large gravel bed alluvial rivers associated to plurispecific fish communities (Souchon et al., 2002), other habitat features are needed to predict fish assemblages (Powers et al., 2003). Refuge availability and proximity to the riparian zone are two variables that have been shown to be strong predictors of fish assemblages (Copp \& Jurajda, 1999; Schiemer, Keckeis \& Flore, 2001). Both of these variables are proxies for the availability of refuges (Growns, Pollard \& Gehrke, 1998) as well as shading zones, organic matter and favoured feeding areas (Gozlan et al., 1999; Hirzinger et al., 2004). Species richness (Powers et al., 2003) and densities (Shields, Knight \& Cooper, 1994) are also strongly correlated with channel width.

Although earlier studies often considered the importance of local scale variables as drivers of stream diversity, recent studies have shown the importance of catchment level variables (Ward \& Stanford, 1989; Townsend et al., 2003). Moreover, as mechanisms may operate on scales other than those at which patterns are observed they may be best understood by the assessment of relationships within smaller scale units, within large scale units (Levin, 1992; Moir, 2008). Consequently, relating processes identified at a local scale to large scale phenomena is a major challenge of both fundamental and applied ecology. For this reason, we describe habitat at local and mesohabitat scales. We study the importance of the classical 
variables, water depth, current velocity and roughness height, as well as proximity to the bank, presence of large woody debris and channel width, as predictors of fish assemblages. Furthermore, using two distinct hydromorphological periods separated by almost 10 years we test the hypothesis that relationships between fish assemblages and spatial habitat are consistent among years. The study was carried out in a highly regulated river which has experienced stable low flow conditions and a significant decrease in minor floods since the construction of the Serre-Ponçon dam in late 1950's; dam construction resulted in flows of $1 / 40^{\text {th }}$ of pre-regulated annual mean discharges. Finally, although much is known of the effects of flow regulation on salmonids (Murchie et al., 2008), our study focused on rheophilic cyprinids.

\section{METHODS}

\section{Study area}

The catchment of the Durance River $\left(14322 \mathrm{~km}^{2}\right)$, the last left-bank tributary of the Rhône River, starting at about $2400 \mathrm{~m}$ a.s.l. at the Franco-Italian border, merges with Rhône River some $320 \mathrm{~km}$ downstream. Having a Mediterranean climate, the Durance catchment receives less annual precipitation than other alpine tributaries of the Rhône (annual mean rainfall 720$900 \mathrm{~mm}$ in the Durance catchment; data from Météo-France, 1961-1990, AURELHY model). The upper Durance has a nival flow regime, not much influenced by glacial inputs, but the influence of Mediterranean climate increases with decreasing altitude (Pardé, 1925).

The study site is a reach of about one kilometre long, located near Manosque (Alpes-deHaute-Provence, Latitude: $43^{\circ} 50^{\prime} 26^{\prime \prime}$ N, Longitude: $05^{\circ} 51^{\prime} 06^{\prime \prime}$ E) (Fig. 1). The study focused on the residual channel of the initial braided alluvial river pattern (Warner, 2000). Before flow regulation, annual discharge averaged $140 \mathrm{~m}^{3} . \mathrm{s}^{-1}$, and the natural minimum flow 
was $c .24 \mathrm{~m}^{3} \cdot \mathrm{s}^{-1}$. After flow regulation, discharge has markedly decreased (to $c .3 .5 \mathrm{~m}^{3} . \mathrm{s}^{-1}$ ), with interspersed winter or spring flood events from intermediate sub-catchments (Fig. 2). Low discharge has resulted in a single channel, with few connections to residual side channels and backwaters, an increased remoteness of favourable structures for fish, such as shade and cover, and a reduction in river bank heterogeneity. The physical habitat is essentially built around gravel point, mid-channel, diamond and diagonal bars (Kellerhals \& Church, 1989). These features explain the main physical characteristics of the regulated middle Durance River (Table 1).

\section{Fish assemblage}

Fish were sampled from 289 independent homogeneous sample units by diurnal electrofishing (EFKO F.E.G. 8000, 400-600 V, 6-10 A) using an open-sampling technique (Lamouroux et al., 1999b; Thevenet \& Statzner, 1999; Lamouroux et al., 2006). As larger individuals have a better escape response, an adapted long anode of four metres was used to prospect deep areas and reduce fish escape. Surfaces varied between 4.5 and $110 \mathrm{~m}^{2}$ (95\% of units). Lamouroux et al. (1999a) showed that the area of sample units had a negligible impact on preference models.

All individuals were identified to species (except for young stages of the two species of the genus Chondrostoma which were grouped), and total length (TL $\pm 1 \mathrm{~mm}$ ) measured. For analysis, each species was divided into size or taxa classes as: taxon $1(0<\mathrm{TL} \leq 30 \mathrm{~mm})$, taxon $2(30<\mathrm{TL} \leq 60 \mathrm{~mm})$, taxon $3(60<\mathrm{TL} \leq 90 \mathrm{~mm})$, taxon $4(90<\mathrm{TL} \leq 120 \mathrm{~mm})$, taxon $5(120<\mathrm{TL} \leq 150 \mathrm{~mm})$, taxon $6(150<\mathrm{TL} \leq 300 \mathrm{~mm})$, taxon $7(300<\mathrm{TL} \leq 450 \mathrm{~mm})$ and taxon $8(\mathrm{TL}>450)$. Rarest species were excluded from statistical analysis. 
Annual sampling campaigns were carried out from July until September during five years, grouped in two periods (1995-1996-1997 and 2004-2005). Sampling was done when physical constraints linked to regulated low flow and water temperature were the highest and when all fish size classes, in particular the young-of-the-year, could be obtained (Gozlan et al., 1999). The first period was characterised by flood events between each annual campaign, whilst the second period was characterised by a long and stable hydrological period due to the absence of high flow events (Fig. 2).

\section{Habitat characteristics}

A specific digital elevation model (DEM) was developed and used to describe hydraulic variability in the study reach (e.g. quantification of the proportions of velocity-depth classes). For a given flow and for any area of the aquatic space, it was possible to quantify the hydraulic diversity by calculating the percentages of volumes or horizontal surfaces in a depth-average velocity cross-classification. This representation in the velocity-depth plane is known as a hydraulic signature (Le Coarer, 2005; Le Coarer, 2007).

Geo-referencing of vertical measurements of depths and corresponding average velocities was done with a TCRA 1102 (C) LEICA). Density of verticals increased according to the local heterogeneity of geomorphic units. Current velocities were measured using an electromagnetic current metre (FLO-MATE, portable model 2000). Discharge was gauged during each sampling period. Each year, the complete topography, depth and velocity measurements, gave a precise cartography of the study reach.

A more exhaustive habitat description was done for each of the individual sampling sub-units for fish. Within each sub-unit, a minimum of nine verticals of water depth and current 
velocity were spatialised to build a triangular irregular network (TIN) of hydraulic description. Using the Hydrosignature concept, we defined nine depth-velocity crossed classes (i.e. hydraulic classes, Table 2). The lower velocity class limit $\left(5 \mathrm{~cm} . \mathrm{s}^{-1)}\right.$ separates lentic zones and the upper value $\left(30 \mathrm{~cm} . \mathrm{s}^{-1}\right)$ corresponds to the observed critical velocity for suspended load transport. Values for depth were chosen according to Aadland's (1993) classification of stream habitat types.

Substratum type was characterized by measuring roughness height $(\mathrm{k})$, defined as the difference between the highest point on a particle and the minimal height of contact points of adjacent particles (Gordon, McMahon \& Finlayson, 1992). A minimum of 10 values were measured in each sample unit and divided into five classes (Table 3). Large woody debris (LWD) was recorded as percent cover according to three classes $(W 1<10 \%$, $10 \leq W 2<50 \%, W 3 \geq 50 \%$ ). This form of assessment is well adapted to large systems presenting low density and discrete distributions of LWD (Maridet \& Souchon, 1995; Thevenet, Citterio \& Piegay, 1998). Segments were created from shorelines and cover percentages incremented into a GIS. The shortest distances were then measured from the centroid of each sample unit to each modality of cover $\left(d_{-} W 1, d_{-} W 2\right.$ and $\left.d_{-} W 3\right)$ and to the bank (dBank). Channel width was also recorded (Width) (Table 3). The last two variables were chosen according to the asymmetry of transversal fish distribution in a channel and the importance of instream ecotones (Bretschko \& Waidbacher, 2001).

For the global approach, 10 types of visually distinguishable and biologically meaningful mesohabitats were identified (Table 4), and associated surfaces were evaluated each sampling year. Mesohabitat classes were defined according to the criteria proposed by Borsanyi (2004) and Malavoi \& Souchon (2002). 


\section{Analysis}

\section{Importance of habitat}

Partial Least Square regression (PLS) was used to quantify the influence of habitat variables on the spatial patterns of fish assemblages. As regression coefficients are not independent among fish taxa, they were ranked and analysis done on the first three variable ranks. Distances were square-root transformed and fish densities (abundance. $\mathrm{m}^{-2}$ ) were $\log (\mathrm{x}+1)$ transformed to account heteroscedasticity and deviations from normality. As values of coefficients associated to distances were inversely related to proximity to these structures, the signs of the coefficients were reversed and referred to as: Bank, Wood1, Wood2 and Wood3. Bootstrapping was used to assess the distribution of the rank variables denoting the relative importance of each descriptive variable, according to Austin \& Tu (2004) and adapted for study needs.

In order to transpose information collected at the sample unit scale to the reach scale, we used 10000 simulations of the simulated surface areas of each mesohabitat, with a Dirichlet variable (Lange, 2002). Using parameters observed at the reach scale, we generated a bootstrapped data set in order to represent habitat diversity observed at the studied reach. Coefficients ranks were computed for the 10000 resampled data sets using pls package for $\mathrm{R}$ (Kooistra et al., 2001). Interpretation of the results focused on the first three variable ranks (rank one being the number of times the descriptive variable had the most influence on fish presence).

Importance of temporal stability 
Temporal stability of spatial relationships between the two sampling periods was tested using PLS. First, the same data processing as in previous analysis (bootstrapping including PLS regression) was carried out but restricted to 100 PLS regressions. The resulting two rank matrices were simplified: only taxa from the eight dominant species (blageon - Leuciscus souffia, stream bleak - Alburnoides bipunctatus, chub - Leuciscus cephalus, stone loach Barbatula barbatula, barbel - Barbus barbus, minnow - Phoxinus phoxinus, sofie Chondrostoma toxostoma and gudgeon - Gobio gobio) and habitat variables: (i) Wood3 (proximity to the most complex LWD), (ii) Bank (proximity to the bank), (iii) $k 1, k t$ ( $k 2, k 3$ and $k 4$ grouped) and $k 5$ and (iv) $D 1 V 1, D 1 V 2, D 1 V 3, D 2 V 1, D 2 V 2, D 2 V 3$ with depth limits $(D 1 \leq 30 \mathrm{~cm}, D 2>30 \mathrm{~cm})$ and velocity limits $\left(V 1 \leq 5 \mathrm{~cm} \cdot \mathrm{s}^{-1}, 5 \mathrm{~cm} \cdot \mathrm{s}^{-1}<V 2 \leq 30 \mathrm{~cm} . \mathrm{s}^{-1}\right.$ and $V 3$ $>30 \mathrm{~cm} \cdot \mathrm{s}^{-1}$ ) were used.

Simulated rank distribution of each variable for each taxon was compared using a $t$-test. The resulting p-values matrix was considered as an observed situation between the two data sets. New data sets were generated using the assumption that spatial relationships were similar among years. For this, and as bootstrapped Student $t$-statistic asymptotic properties were not known (Mason \& Shao, 2001), permutation tests were performed (Manly, 1997). All sample units were combined and permutations were carried out in order to rebuild 1000 replicates of both data sets including data from all years. For each permutation, the same data processing was undertaken and the resulting distribution of statistics from these $1000 t$-tests was considered as a theoretical situation (i.e. if there were no fish species preferences). The relative positions of the p-values associated to the observed situation within the distribution of the $1000 \mathrm{p}$-values obtained for the theoretical situation informed us about the probability of the observed situation under null hypothesis of stability of relationships among years. 

All analysis were conducted using $\mathrm{R}$ software version 2.2.1 $\quad$ C 2005 (R_Development_Core_Team, 2005).

\section{RESULTS}

\section{Fish assemblages}

The studied reach of the middle Durance was characterised by 18 fish species from six families and was mainly dominated by rheophilous cyprinids (Table 5). Six species made up 85\% of captures: five cyprinids (blageon, stream bleak, chub, barbel, minnow) and one balitorid, the stone loach. Four intermediate species counted for about $14 \%$ of captures: three cyprinids (nase - Chondrostoma nasus, sofie, gudgeon) and one cobitid, the spined loach (Cobitis bilineata). Eight rare species represented 1.3\% of the total number of captures: three cyprinids (bleak - Alburnus alburnus, roach - Rutilus rutilus and tench - Tinca tinca), two percids (perch - Perca fluviatilis and Rhône streber - Zingel asper), one centrarchid (pumpkinseed - Lepomis gibbosus) and two salmonids (brown trout - Salmo trutta and rainbow trout - Oncorhynchus mykiss). Two species deserve particular attention: the Rhône streber, a threatened endemic species of the Rhône catchment, and the introduced spined loach. Thirty-one individuals of Rhône streber were recorded in 20 sample units during the five sampling campaigns. This species is considered as critically endangered in the International Union for Conservation of Nature and Natural Resources (IUCN) Red list of threatened species (Crivelli, 2006). The spined loach was also caught in the studied reach; first observed in the Durance River in 1996 after successive high floods, and captures increased from 14 specimens in the first period to 176 specimens in the second period. 
Most individuals of the fish assemblage consisted of young-of-the-year and small species ( $c$. 75 percent were $<90 \mathrm{~mm}$ ). Only $0.65 \%$ of total fish catch were longer than $300 \mathrm{~mm}$. For large cyprinids, adults $>300 \mathrm{~mm}$ accounted $0.8 \%, 2 \%$ and $6.5 \%$ of chub, barbel and nase, respectively.

\section{Habitat characteristics}

Instream flow varied from 3.5 to $7 \mathrm{~m}^{3} \cdot \mathrm{s}^{-1}$, and width of active channel varied from 7 to $202 \mathrm{~m}$ (mean $33 \mathrm{~m}$ ) during the study period (Table 1). Cross-section flow velocities (mean $0.44 \mathrm{~m} . \mathrm{s}^{-}$ 1 , range $0.05-1.85 \mathrm{~m} . \mathrm{s}^{-1}$ ) and water depth (mean $0.36 \mathrm{~m}$, range $0.04-1.11 \mathrm{~m}$ ) showed a predominance of shallow and lentic habitats. Deep areas $>60 \mathrm{~cm}$ covered $13.5 \%$ of the reach compared to $26.2 \%$ for shallow areas $(\mathrm{d}<15 \mathrm{~cm}$, Table 2$)$. The proportion of large and shallow riffles increased. A first topographical survey of $3300 \mathrm{~m}$ resulted in the presence of 10 riffles of $25 \mathrm{~m}$ or more with a depth $<15 \mathrm{~cm}$ (Dumont et al., 1993).

During regulated flow conditions the alluvial forest is almost always far from the channel and reached only during floods. Inputs of large woody debris from riparian forest to the channel were highly reduced. The scarcity of immersed LWD was indirectly shown by the average

minimal distance between sample units and woody debris (d_W3: $64 \mathrm{~m}, \mathrm{~d}$ _W2: $81 \mathrm{~m}, \mathrm{~d}$ _W1: $84 \mathrm{~m}$, Table 3), i.e. twice the width of the active channel.

The first 16 principal components of the PLS regression were kept in order to explain at least $25 \%$ of the spatial patterns individual taxa. Including more components did not improve model fit. The first three ranks obtained from the coefficients of the PLS regression (Appendix 1) revealed strong relationships between fish length and hydraulic classes. A well 
defined pattern for the largest species (chub, barbel and nase) was exhibited. Some hydraulic classes were strongly avoided, such as d1v1 by large taxa, d1v4 by minnow and $\mathrm{d} 4 \mathrm{v} 1$ by bleak (Aal $2 \&$ 3), blageon (Lso $4 \&$ 5), chub (Lce 2 to 6), nase (Cna $4 \& 5$ ) and all taxa of spined loach.

Habitat characteristics were important predictors of fish assemblage composition. Presence or proximity of LWD had a significant effect on the largest specimens of sofie, gudgeon, perch, chub, blageon, nase and barbel, and also on all size classes of stream bleak. LWD was also the most important variable for nase (Cna 6), gudgeon (Ggo 4 \& 5) and perch (Pfl 6). By contrast, other taxa, bleak (Aal 3 \& 4), young sofie (Cto 3) and barbel (Bbs 3) and Rhône streber (Zas 2) were negatively correlated with LWD. A positive effect of bank proximity was also observed for almost all species, particularly for the youngest fishes, in relation to low depths close to the bank. Bank proximity was also important for some large taxa such as chub, barbel and perch. Conversely, bank proximity was not important for spined loach, and Rhône streber was negatively correlated with this variable. Regarding channel width, most of the species occupied the narrow sections of the river, except Rhône streber (taxa 3, 4 \& 5) which showed a preference for large channels and an avoidance of bank proximity. All sizes of species caught in lentic sub-units (chub, spined loach, perch) but also some rheophilous taxa (bleak, gudgeon, blageon) were associated to the lowest roughness height values $(\mathrm{k} 1)$. The largest rheophilic species (nase, sofie, barbel, blageon) were associated to the highest k values (k5) recorded in narrow and curved sections of the channel with the highest hydraulic classes. In some areas, rheophilic species were associated to heavy blocks used for bank stabilisation.

Our results show the importance of habitat for the endangered Rhône streber and two loaches (stone and spined loach). Small individuals $(<60 \mathrm{~mm}$ ) were mainly associated with $\mathrm{d} 2 \mathrm{v} 3$ 
while the larger individuals $(>60 \mathrm{~mm})$ were only associated with $\mathrm{d} 2 \mathrm{v} 4(\mathrm{~d} 2 \mathrm{v} 3$ were partly avoided). Rhône streber inhabited mid-channels in wide sections. Roughness height followed a gradient in intermediate $\mathrm{k}$ classes according to the fish size ( $\mathrm{k} 4$ was avoided by taxa 3 and 4). The stone loach was mainly found in fast-flowing shallow zones (overall $<0.05 \mathrm{~m}$ ) and appeared to be directly influenced by proximity to the bank or to the largest woody debris. By contrast, the spined loach was only observed in null velocity areas; according to rank values, this species was associated to the presence of very fine $(\mathrm{k} 1)$ substratum.

\section{Temporal variability}

Hydromorphological changes in the river bed and instream LWD after high-level floods showed the most marked changes between the two time periods (Fig. 2). Although \% bank line with LWD did not differ among years (range 2.6\% in 1996 to $7 \%$ in 1995), distance to the nearest and highest complex LWD (d_W3) did differ between the two periods (Period 1: $99 \pm 21 \mathrm{~m}$, Period 2: $35 \pm 5 \mathrm{~m}$, Mann-Whitney test, $\mathrm{P}<0.001)$ (Table 6). Distances to the bank did not differ (Period 1: $4.9 \pm 0.8 \mathrm{~m}$, Period 2: $6.1 \pm 0.8 \mathrm{~m}, \mathrm{P}=0.078$ ), whereas roughness height classes differed significantly for k1 and k5. Silted areas increased in 2005 and roughness height increased in the last two years (Table 3).

As the river channel was not restructured between 2004 and 2005, the sampled surface associated to $\mathrm{k} 1$ in $2005(10.8 \%$ ) was about twice that of other years (mean 5.3\%). Furthermore, in the second period, a reach section was running along rocks protecting a motorway, increasing "artificially" high roughness height values (sampled surface associated to $\mathrm{k} 5$ was about $2.5 \%$ in $2004-2005$, whereas it was less than $0.6 \%$ for the other three years). 
In spite of changes in habitat characteristics, no major differences in fish-habitat relationships were noted between the study periods (Table 6). The importance of bank characteristics was the same between periods except for stream bleak (Abi 4). Only one strong ecological change concerned proximity to the nearest large woody debris (blageon, Lso 5) and roughness height (stream bleak, Abi 2 for k1). Similarly, few differences were noted for hydraulic classes between periods (Table 2). The most important changes were noted in D2V1 class for chub (Lce 2 \& 6) and in D2V3 for barbel (Bbs 6). Observed differences in hydrosignatures were mainly related to deep classes $(\mathrm{d}>60 \mathrm{~cm})$. A deepening of the channel against the artificial bank reinforcement consecutive to its lateral migration explained the highest proportion of deep classes during the second period.

\section{DISCUSSION}

River topography and quantitative hydraulic characterisation of habitat (Le Coarer \& Dumont, 1995; Le Coarer, 2005; Le Coarer, 2007) were used to define the hydraulic heterogeneity of each sub-unit. Traditionally, water depth and current velocity are considered as independent parameters, although they are intimately associated, for example, in characterisation of physical flow (Stewardson \& McMahon, 2002), ecological mesohabitat evaluation (Orth, 1995) and fish habitat use (Mosley, 1983; Aadland, 1993). Bivariate classes (depth/velocity) and use of fish size classes highlighted taxa distributions according to the size, physiological adaptation and ecological affinity to hydraulic conditions. Taxa followed well-defined gradual distribution in hydraulic classes.

Our results show the importance of habitat characteristics for fish assemblages, but also that depths used by taxa, especially large individuals, were probably a "compulsory" adjustment to 
physical conditions rather than a real preference in the Durance (Boyer, 2004). Only $13.5 \%$ of the study reaches consisted of deep mesohabitat $(\mathrm{d}>60 \mathrm{~cm})$, which is known to be important in the life history of large rheophilous species (Baras \& Cherry, 1990; Lucas \& Batley, 1996; Huber \& Kirchhofer, 1998; Allouche, Thevenet \& Gaudin, 1999). Hence, the scarcity of deep mesohabitat is likely responsible for the low number of large individuals recorded in our study. Only $0.8 \%$ of chub, $2 \%$ of barbel and $6.5 \%$ of nase individuals captured were $>300$ mm. Although sampling effort may have underestimated the density of large individuals, our findings support previous studies on the regulated Durance (Bouchard, 1996; Dumont et al., 1993). The low number of large individuals could also be associated to fitness which may be negatively affected by physical constraints, such as low availability of LWD, decrease in mean current velocity, lack of deep areas and alteration of temperature patterns. All of these disturbances have been shown to affect the growth rate of salmonids (Swales, 1988; Fausch \& Northcote, 1992) and chub (Bouchard et al., 1998) in the river Durance.

The finding that substratum roughness height value $(\mathrm{k})$ was a robust predictor of fish assemblages was expected as it indirectly estimates hydraulic shelter created by substratum elements. A previous study in a salmonid-rich part of the regulated Durance showed a significant positive relationship between mean size of brown trout and mean $\mathrm{k}$ value in subunits (Carrel et al., 1992). The importance of the $\mathrm{k} 1$ class is related to fine sediments associated with low velocity; only Cobitis bilineata can be considered as having a real affinity to fine sediment substratum (Slavik et al., 2000). Intermediate $\mathrm{k}$ classes had no clear influence on the spatial patterns of individual taxa, with the exception of Rhône streber. Our results corroborate Rhône streber habitat observations on the Beaume River, a tributary of the Ardèche River (Labonne, Allouche \& Gaudin, 2003). The k5 class appears naturally in the 
deepest areas and in artificial rocks protecting the bank (second period). The large substrate elements are mainly used as cover for the largest specimens.

Woody debris was among the first three variables selected in our models, and its importance is clearly highlighted regarding the influence of LWD on rank values. This strong relationship is likely related to the overall low amount of LWD in the study reaches, but also its importance for instream hydrology and shelter. The largest woody debris (and associated distances: d_W2 and d_W3) had the most influence on fish assemblages. Thevenet, Citterio \& Piegay (1998) showed that wood jams containing large wood had greater potential for aquatic communities. Likewise, Angradi et al. (2004) showed the importance of LWD for increasing habitat heterogeneity, by increasing the hydraulic roughness of the bed and creating specific habitats, for fish assemblages.

Species richness and spatial responses of taxa were relatively stable, despite large hydromorphological changes during flood events. The main differences between the study periods were associated with changes in morphological characteristics following natural high flood events and siltation during long periods of stable low flow. The significant changes in distances to the nearest LWD observed between the two periods could be linked to migration patterns of the channel, thereby underpinning the importance of contact with forested bank. Our results showed low LWD densities in the channel in addition to the highest densities unusually being found in the channel sections reaching overhanging residual alluvial forests. Differences observed for Wood3 were explained by greater distances to these LWD during the first period. For example, distances for blageon to the nearest largest LWD were clearly distinct between the first (mean $78.3 \mathrm{~m}$ ) and second $(14.5 \mathrm{~m}$ ) periods. For bank variability, the differences observed for stream bleak were explained by the shorter distance to the bank 
recorded the first year $(1.8 \pm 1.1 \mathrm{~m}$ in 1995$)$ compared to the other years $(6.1 \pm 0.9 \mathrm{~m})$. The only difference exhibited in roughness height was associated with stream bleak for $\mathrm{k} 1$ and was related to the increase in silted areas in 2005.

Spatio-temporal relationships for hydraulic classes showed the regulated Durance to be relatively stable during the study period. Significant differences concerned chub for class D2V1 and barbel for class D2V3. Chub preferred habitats with low water velocity, greater depth and wood shelter (Appendix 1). During the first study period, chubs were often sampled in sub-units close to or inside wood cover, i.e. woody debris functioned as a hydraulic refuge. The observed differences were therefore related more to the choice of hydraulic class limits than to a real change in velocity preference of the species. Barbel was associated with deep, fast-flowing habitats located along rip rap. Despite high levels of disturbance, both fish assemblages and spatio-temporal relationships of individual taxa to habitat characteristics appeared relatively stable.

Prior to large scale regulation of the middle Durance River the fish community was practically unknown, except for some rare historical data published in cartographical archives. Studies by Kreitman (1932) and Leger (1934) provide historical data on fish assemblages in the Rhône River and Upper Durance catchment, respectively. A comparison of current with past conditions showed fish assemblages in the main channel to be similar, with the exception of eel (Anguilla anguilla), which has totally disappeared from the middle Durance, and the recent arrival of Cobitis bilineata. Indeed, before the first capture of a cobitid in the Durance, Cobitis taenia was considered as the only spined loach present in France, mainly limited to the Seine and the Rhine catchments (Keith \& Allardi, 2001). The diversity of hydrosystems inhabited by $C$. bilineata could explain its rapid and successful colonisation of the River 
Durance (Kottelat \& Freyhof, 2007). By contrast, the distribution of the endemic percid Zingel asper has dramatically decreased in the Rhône River catchment (Laroche \& Durand, 2004). Therefore, a population of the endemic Zingel asper in the highly regulated middle Durance can be considered as a positive element for its conservation.

Many studies have demonstrated that an efficient restoration plan cannot rely solely on smallscale actions such as implantation of artificial instream structures or rehabilitation of the main channel (Pretty et al., 2003). Potential recovery of fish assemblages in the Durance River is driven by the necessity of promoting the development of lateral and off-channel habitats within the river corridor. Sustainable management implies an efficient rehabilitation scheme including a regulated instream flow that should be more adapted to fish needs. Coupling information on mesohabitat and at reach scale was demonstrated to be the best way of assessing and predicting fish spatial assemblages (Parasiewicz \& Walker, 2007). Although restoration would require improving natural hydro-geomorphological dynamics in order to increase habitat heterogeneity, with connections to remnant side channels or backwaters, it would be most effective when used together with other strategies such as water quality management. Consequently, explaining how these abiotic and biotic factors interact over a range of temporal and spatial scales should be a major goal of lotic fish ecologists (Schlosser, 1995).

In regulated rivers, many landscape attributes have been shown to have strong effects on processes determining fish population dynamics. The functional terrestrial-aquatic ecotone and its influence on temporal and spatial variation in resource or cover supply were shown to significantly affect the distribution fish species and assemblages. Large-scale spatial habitat relationships and their effects on resource use and fish movement are likely to be most 
relevant for modelling. Presence of refuges from harsh environmental conditions and their influence on fish survival and emigration/immigration rates must be taken into account to increase fish populations.

\section{ACKNOWLEDGMENTS}

We thank all past and present members of the Hydrobiology unit at Cemagref (Aix en Provence) for their help during sampling periods and data analysis. Special thanks to Maxime Logez for his reviews in data modelling. We thank anonymous reviewers for helpful comments that substantially improved earlier versions of the manuscript. Data for the first three years are the propriety of Electricite De France (EDF). Financial support for this study was provided by the Region Provence-Alpes-Côte d'Azur. Hydrosignature software is available at http://hydrosignature.aix.cemagref.fr/ 


\section{REFERENCES}

Aadland L.P. (1993) Stream habitat types: their fish assemblages and relationship to flow. North American Journal of Fisheries Management, 13, 790-806.

Aarts B.G.W., Van Den Brink F.W.B. \& Nienhuis P.H. (2004) Habitat loss as the main cause of the slow recovery of fish faunas of regulated large rivers in Europe: The transversal floodplain gradient. River Research and Applications, 20, 3-23.

Abdi H. (2007) Partial least square regression (PLS regression). In: Encyclopedia of Measurement and Statistics, vol. (Ed. N.J. Salkind), pp. 740-744. Sage, Thousand Oaks, CA, USA.

Allouche S., Thevenet A. \& Gaudin P. (1999) Habitat use by chub (Leuciscus cephalus L. 1766) in a large river, the French Upper Rhone, as determined by radiotelemetry. Archiv für Hydrobiologie, 145, 219-236.

Angradi T.R., Schweiger E.W., Bolgrien D.W., Ismert P. \& Selle T. (2004) Bank stabilization, riparian land use and the distribution of large woody debris in a regulated reach of the upper Missouri River, North Dakota, USA. River Research and Applications, 20, 829-846.

Austin P.C. \& Tu J.V. (2004) Bootstrap methods for developing predictive models. American statistician, 58, 131-137.

Baras E. \& Cherry B. (1990) Seasonal activities of female barbel Barbus barbus (L.) in the River Ourthe (Southern Belgium), as revealed by radio tracking. Aquatic Living Resources, 3, 283-294.

Borcherding J., Bauerfeld M., Hintzen D. \& Neumann D. (2002) Lateral migrations of fishes between floodplain lakes and their drainage channels at the Lower Rhine: diel and seasonal aspects. Journal of Fish Biology, 61, 1154-1170.

Borsanyi P., Alfredsen K., Harby A., Ugedal O. \& Kraxner C. (2004) A meso-scale habitat classification method for production modelling of Atlantic salmon in Norway. Hydroécologie Appliquée, 14, 119-138.

Bouchard P. (1996) Dynamique spatio-temporelle des peuplements ichtyologiques de la Durance aménagée. Doctorat de l'Université de Provence, Université de Provence, Aix-Marseille.

Bouchard P., Chappaz R., Cavalli L. \& Brun G. (1998) Influence of environmental variables on the growth of Leuciscus cephalus (Linnaeus 1766), in the River Durance, Southeast France. Annales de Limnologie, 34, 193-200.

Bovee K.D. (1982) A guide to stream habitat analysis using the instream flow incremental methodology. 12, U.S. Department of the Interior, Fish and Wildlife Service, Office of Biological Services.

Boyer J. (2004) 5M7, un modèle de préférence d'habitat pour les poissons d'eau courante : test et validation. Master thesis, Environnement et Développement Durable, Option FGMAM, Université de Perpignan.

Bravard J.-P., Amoros C., Pautou G., Bornette G., Bournaud M., Creuze Des Chatelliers M., Gibert J., Peiry J.-L., Perrin J.-F. \& Tachet H. (1997) River incision in South-East France: morphological phenomena and ecological effects. Regulated Rivers Research \& Management, 13, 75-90.

Bretschko G. \& Waidbacher H. (2001) Riparian ecotones, invertebrates and fish: life cycle timing and trophic base. In: Catchment processes land/water ecotones and fish communities, vol. 1, (Eds M. Zalewski, F. Schiemer \& J. Thorpe), pp. 57-64. Ecohydrology and Hydrobiology, Warsaw, Poland.

Brosse S. \& Lek S. (2000) Modelling roach (Rutilus rutilus L.) microhabitat using linear and nonlinear techniques. Freshwater Biology, 44, 441-452. 
Brunke M. \& Gonser T. (1997) The ecological significance of exchange processes between rivers and groundwater. Freshwater Biology, 37, 1-33.

Bunn S.E. \& Arthington A.H. (2002) Basic principles and ecological consequences of altered flow regimes for aquatic biodiversity. Environmental management, 30, 492-507.

Carrel G., Dumont B., Le Coarer Y. \& Rivier B. (1992) Morphodynamique et biologie piscicole de la Durance dans le secteur Espinasses-Rochebrune (aval de SerrePonçon). Division Hydrobiologie, Cemagref Aix-en-Provence, Le Tholonet.

Chipps S.R., Perry W.B. \& Perry S.A. (1994) Fish assemblages of the central Appalachian Mountains: an examination of trophic group abundance in nine West Virginia streams. Environmental Biology of Fishes, 40, 91-98.

Copp G.H. (1989) The habitat diversity and fish reproductive function of floodplain ecosystems. Environmental Biology of Fishes, 26, 1-27.

Copp G.H. \& Jurajda P. (1999) Size-structured diel use of river banks by fish. Aquatic Sciences, 61, 75-91.

Corbacho C. \& Sanchez J.M. (2001) Patterns of species richness and introduced species in native freshwater fish faunas of a mediterranean-type basin: The Guadiana River (southwest Iberian Peninsula). Regulated Rivers - Research \& Management, 17, 699707.

Crivelli A.J. (2006) Zingel asper [online]. 2007 IUCN Red List of Threatened Species.

Doledec S., Lamouroux N., Fuchs U. \& Merigoux S. (2007) Modelling the hydraulic preferences of benthic macroinvertebrates in small European streams. Freshwater Biology, 52, 145-164.

Dufour S., Barsoum N., Muller E. \& Piegay H. (2007) Effects of channel confinement on pioneer woody vegetation structure, composition and diversity along the River Drome (SE France). Earth Surface Processes and Landforms, 32, 1244-1256.

Dumont B., Le Coarer Y. \& Carrel G. (1993) Moyenne Durance. Site du Largue. Etude du débit réservé. Morphodynamique et ichtyologie. CEMAGREF, Division Hydrobiologie, Aix-en-Provence, France.

Dunham J.B. \& Rieman B.E. (1999) Metapopulation structure of bull trout: Influences of physical, biotic, and geometrical landscape characteristics. Ecological Applications, 9, 642-655.

Fausch K.D. \& Northcote T.G. (1992) Large woody debris and Salmonid habitat in a small coastal British Columbia stream. Canadian Journal of the Fisheries and Aquatic Sciences, 49, 682-693.

Gordon N.D., McMahon T.A. \& Finlayson B.L. (1992) Stream hydrology: an introduction for ecologists. John Wiley \& Sons Ltd, Chichester.

Gorman O.T. \& Karr J.R. (1978) Habitat structure and stream fish communities. Ecology, 59, 507-515.

Gozlan R.E., Mastrorillo S., Copp G.H. \& Lek S. (1999) Predicting the structure and diversity of young-of-the-year fish assemblages in large rivers. Freshwater Biology, 41, 809820.

Gozlan R.E., Mastrorillo S., Dauba F., Tourenq J.N. \& Copp G.H. (1998) Multi-scale analysis of habitat use during late summer for $0+$ fishes in the River Garonne (France). Aquatic Sciences, 60, 99-117.

Growns I.O., Pollard D.A. \& Gehrke P.C. (1998) Changes in river fish assemblages associated with vegetated and degraded banks, upstream of and within nutrientenriched zones. Fisheries Management and Ecology, 5, 55-69.

Hirzinger V., Keckeis H., Nemeschkal H.L. \& Schiemer F. (2004) The importance of inshore areas for adult fish distribution along a free-flowing section of the Danube, Austria. River Research and Applications, 20, 137-149. 
House R.A. \& Boehne P.L. (1986) Effects of instream structures on salmonid habitat and populations in Tobe Creek, Oregon. North American Journal of Fisheries Management, 6, 38-46.

Huber M. \& Kirchhofer A. (1998) Radio telemetry as a tool to study habitat use of nase (Chondrostoma nasus L.) in medium-sized rivers. Hydrobiologia, 372, 309-319.

Hunter C.J. (1991) Better trout habitat : a guide to stream restoration and management. Montana Land Reliance.

Keith P. \& Allardi J. (Eds.) (2001) Atlas des poissons d'eau douce de France. Muséum National d'Histoire Naturelle, Paris.

Kellerhals R. \& Church M. (1989) The morphology of large rivers: characterization and management. In: International Large River Symposium (Ed. D.P. Dodge), pp. 31-48. Honey Harbour, Ontario, Canada. Canadian Special Publication of Fisheries and Aquatic Sciences.

Kooistra L., Leuven R.S.E.W., Nienhuis P.H., Wehrens R. \& Buydens L.M.C. (2001) A procedure for incorporating spatial variability in ecological risk assessment of Dutch River floodplains. Environmental Management, 28, 359-373.

Kottelat M. \& Freyhof J. (2007) Handbook of Euroean freshwater fishes. Kottelat \& Freyhorf, Cornol, Switzerland, Berlin, Germany.

Kreitmann L. (1932) Les grandes lignes de l'économie piscicole du bassin français du Rhône. Travaux du Laboratoire d'Hydrobiologie et de Pisciculture de l'Université de Grenoble, 24, 127-131.

Labonne J., Allouche S. \& Gaudin P. (2003) Use of a generalised linear model to test habitat preferences: the example of Zingel asper, an endemic endangered percid of the River Rhone. Freshwater Biology, 48, 687-697.

Lamouroux N., Capra H., Pouilly M. \& Souchon Y. (1999a) Fish habitat preferences in large streams of southern France. Freshwater Biology, 42, 673-687.

Lamouroux N., Olivier J.M., Persat H., Pouilly M., Souchon Y. \& Statzner B. (1999b) Predicting community characteristics from habitat conditions: fluvial fish and hydraulics. Freshwater Biology, 42, 275-299.

Lamouroux N., Olivier J.M., Capra H., Zylberblat M., Chandesris A. \& Roger P. (2006) Fish community changes after minimum flow increase: testing quantitative predictions in the Rhone River at Pierre-Benite, France. Freshwater Biology, 51, 1730-1743.

Lange K. (2002) Mathematical and statistical methods for genetic analysis. New York: Springer-Verlag.

Laroche J. \& Durand J.D. (2004) Genetic structure of fragmented populations of a threatened endemic percid of the Rhône river: Zingel asper. Heredity, 92, 329-334.

Le Coarer Y. (2005) "HydroSignature" software for hydraulic quantification. In: COST 626 European Aquatic Modelling Network. Proceedings from the final meeting in Silkeborg, Denmark 19-20 May 2005, vol. (Eds A. Harby, M. Baptist, H. Duel, M. Dunbar, P. Goethals, A. Huusko, A. Ibbotson, H. Mader, M. Pedersen, S. Schmutz \& M. Schneider), pp. 193-203. National Environmental Research Institute, Silkeborg, Denmark.

Le Coarer Y. (2007) Hydraulic signatures for ecological modelling at different scales. Aquatic Ecology, 41, 451-459.

Le Coarer Y. \& Dumont B. (1995) Modélisation de la morphodynamique fluviale pour la recherche des relations habitat/faune aquatique. Bulletin Français de Pêche et de Pisciculture, 337/338/339, 309-316.

Leahey E. (2005) Alphas and Asterisks: The Development of Statistical Significance Testing Standards in Sociology. Social Forces, 84, 1-24. 
Leger L. (1934) Carte piscicole du département des Hautes Alpes (avec notice explicative et considérations sur l'économie piscicole régionale), 28 pages + carte hors texte. 1/200000. Allier, Grenoble.

Levin S.A. (1992) The problem of pattern and scale in ecology. Ecology, 73, 1943-1967.

Lucas M.C. \& Batley E. (1996) Seasonal movements and behaviour of adult barbel Barbus barbus, a riverine cyprinid fish: Implications for river management. Journal of Applied Ecology, 33, 1345-1358.

Lytle D.A. \& Poff N.L. (2004) Adaptation to natural flow regimes. Trends in Ecology \& Evolution, 19, 94-100.

Malavoi J.R. \& Souchon Y. (2002) Description standardisée des principaux faciès d'écoulement observables en rivière : clé de détermination qualitative et mesures physiques. Bulletin Français de Pêche et de Pisciculture, 365/366, 357-372.

Manly B.F.J. (1997) Randomization, Bootstrap and Monte Carlo Methods in Biology. Chapman \& Hall.

Maridet L. \& Souchon Y. (1995) Habitat potentiel de la truite fario (Salmo trutta fario, L. 1758) dans trois cours d'eau du massif central. Bulletin Français de Pêche et de Pisciculture, 336, 1-18.

Mason D.M. \& Shao Q.-M. (2001) Bootstrapping the Student $t$-statistic. The annals of probability, 29, 1435-1450.

Meffe G. (1984) Effects of abiotic disturbance on coexistence of predator-prey fish species. Ecology, 65, 1525-1534.

Miramont C. (2000) L'histoire du paysage fluvial durancien à l'époque historique. Courrier scientifiques du Parc naturel régional du Lubéron, 4, 110-126.

Moir H.J. \& Pasternack G.B. (2008) Relationships between mesoscale morphological units, stream hydraulics and Chinook salmon (Oncorhynchus tshawytscha) spawning habitat on the Lower Yuba River, California. Geomorphology, 100, 527-548.

Molls F. (1999) New insights into the migration and habitat use by bream and white bream in the floodplain of the Rhine River. Journal of Fish Biology, 55, 1187-1200.

Mosley M.P. (1983) Response of braided rivers to changing discharge. Journal of Hydrology (N.Z.), 22, 18-67.

Moyle P.B. \& Light T. (1996) Biological invasions of fresh water: Empirical rules and assembly theory. Biological Conservation, 78, 149-161.

Mugodo J., Kennard M., Liston P., Linke S., Norris R.H. \& Lintermans M. (2006) Local stream habitat variables predicted from catchment scale characteristics are useful for predicting fish distribution. Hydrobiologia, 572, 59-70.

Murchie K.J., Hair K.P.E., Pullen C.E., Redpath T.D., Stephens H.R. \& Cooke S.J. (2008) Fish response to modified flow regimes in regulated rivers: research methods, effects and opportunities. River Research and Applications, 24, 197-217.

Nilsson C., Reidy C.A., Dynesius M. \& Revenga C. (2005) Fragmentation and flow regulation of the world's large river systems. Science, 308, 405-408.

Ormerod S.J. (2003) Current issues with fish and fisheries: editor's overview and introduction. Journal of Applied Ecology, 40, 204-213.

Orth D.J. (1995) Food web influences on fish population responses to instream flow. Bulletin Français de Pêche et de Pisciculture, 337/338/339, 317-328.

Parasiewicz P. \& Walker J.D. (2007) Comparison of MESOHABSIM with two microhabitat models (PHABSIM and HARPHA). River Research and Applications.

Parde M. (1925) Le Régime du Rhône. Etude hydrologique. Allier, Masson, Grenoble, Lyon.

Piegay H., Thevenet A., Kondolf G.M. \& Landon N. (2000) Physical and human factors influencing potential fish habitat distribution along a mountain River, France. Geografiska Annaler, Series A: Physical Geography, 82A, 121-136. 
Powers S.L., Jones G.L., Redinger P. \& Mayden R.L. (2003) Habitat associations with upland stream fish assemblages in Bankhead National Forest, Alabama. Southeastern Naturalist, 2, 85-92.

Pretty J.L., Harrison S.S.C., Shepherd D.J., Smith C., Hildrew A.G. \& Hey R.D. (2003) River rehabilitation and fish populations: assessing the benefit of instream structures. Journal of Applied Ecology, 40, 251-265.

R_Development_Core_Team (2005) R: A language and environment for statistical computing. R Foundation for Statistical Computing. Vienna, Austria.

Ribes E. \& Provansal M. (2005) Suspended sediment transport and trapping processes in the regulated lower Durance River, southeastern France. In: Geomorphological Processes and Human Impacts in River Basins, vol. 299, (Eds R.J. Batalla \& C. Garcia), pp. 101110. International Association of Hydrological Sciences, Wallingford, England.

Schiemer F., Keckeis H. \& Flore L. (2001) Ecotones and hydrology: key conditions for fish in large rivers. Ecohydrology and Hydrobiology, 1, 49-55.

Schlosser I.J. (1991) Stream fish ecology: a landscape perspective. BioScience, 41, 704-712.

Schlosser I.J. (1995) Critical lanscape attributes that influence fish population dynamics in headwater streams. In: The importance of aquatic-terrestrial ecotones for freshwater fish, vol. 303, (Eds F. Schiemer, M. Zalewski \& J.E. Thorpe), pp. 71-81. Hydrobiologia.

Shields F.D., Jr, Knight S.S. \& Cooper C.M. (1994) Effects of channel incision on base-flow stream habitats and fishes. Environmental Management, 18, 43-57.

Slavik O., Mattas D., Jirinek P., Bartos L. \& Rebec J. (2000) Substratum selection by different sizes of spined loach Cobitis sp. Folia Zoologica, 49, 167-172.

Sokal R.R. \& Rohlf F.J. (1995) Biometry. The principles and practice of statistics in biological research. W. H. Freeman and Company, New York.

Souchon Y., Andriamahefa H., Breil P., Albert M.-B., Capra H. \& Lamouroux N. (2002) Vers de nouveaux outils pour l'aide à la gestion des hydrosystèmes : couplage des recherches physiques et biologiques sur les cours d'eau. Nature Sciences Sociétés, 10, 26-41.

Stewardson M.J. \& McMahon T.A. (2002) A stochastic model of hydraulic variations within stream channels. Water Resources Research, 38.

Swales S. (1988) Fish populations of a small lowland channelized river in England subject to long-term river maintenance and management works. Regulated Rivers - Research \& Management, 2, 493-506.

Thevenet A., Citterio A. \& Piegay H. (1998) A new methodology for the assessment of large woody debris accumulations on highly modified rivers (example of two French piedmont rivers). Regulated Rivers - Research \& Management, 14, 467-483.

Thevenet A. \& Statzner B. (1999) Linking fluvial fish community to physical habitat in large woody debris: sampling effort, accuracy and precision. Archiv für Hydrobiologie, 145, 57-77.

Townsend C.R., Doledec S., Norris R., Peacock K. \& Arbuckle C. (2003) The influence of scale and geography on relationships between stream community composition and landscape variables: description and prediction. Freshwater Biology, 48, 768-785.

Townsend C.R. \& Hildrew A.G. (1994) Species traits in relation to a habitat templet for river systems. Freshwater Biology, 31, 265-275.

Ward J.V. \& Stanford J.A. (1989) Riverine ecosystems: the influence of man on catchment dynamics and fish ecology. In: International Large River Symposium (Ed. D.P. Dodge), pp. 56-64. Honey Harbour, Ontario, Canada. Canadian Special Publication of Fisheries and Aquatic Sciences. 
Warner R.F. (2000) Gross channel changes along the Durance River, Southern France, over the last 100 years using cartographic data. Regulated Rivers - Research \& Management, 16, 141-157.

Warner R.F. (2006) Natural and artificial linkages and discontinuities in a Mediterranean landscape: Some case studies from the Durance Valley, France. CATENA, 66, 236250.

Wilhelm I. (1913) La Durance. Etude de l'utilisation de ses eaux et de l'amélioration de son régime par la création de barrages. Lucien LAVEUR, Paris. 


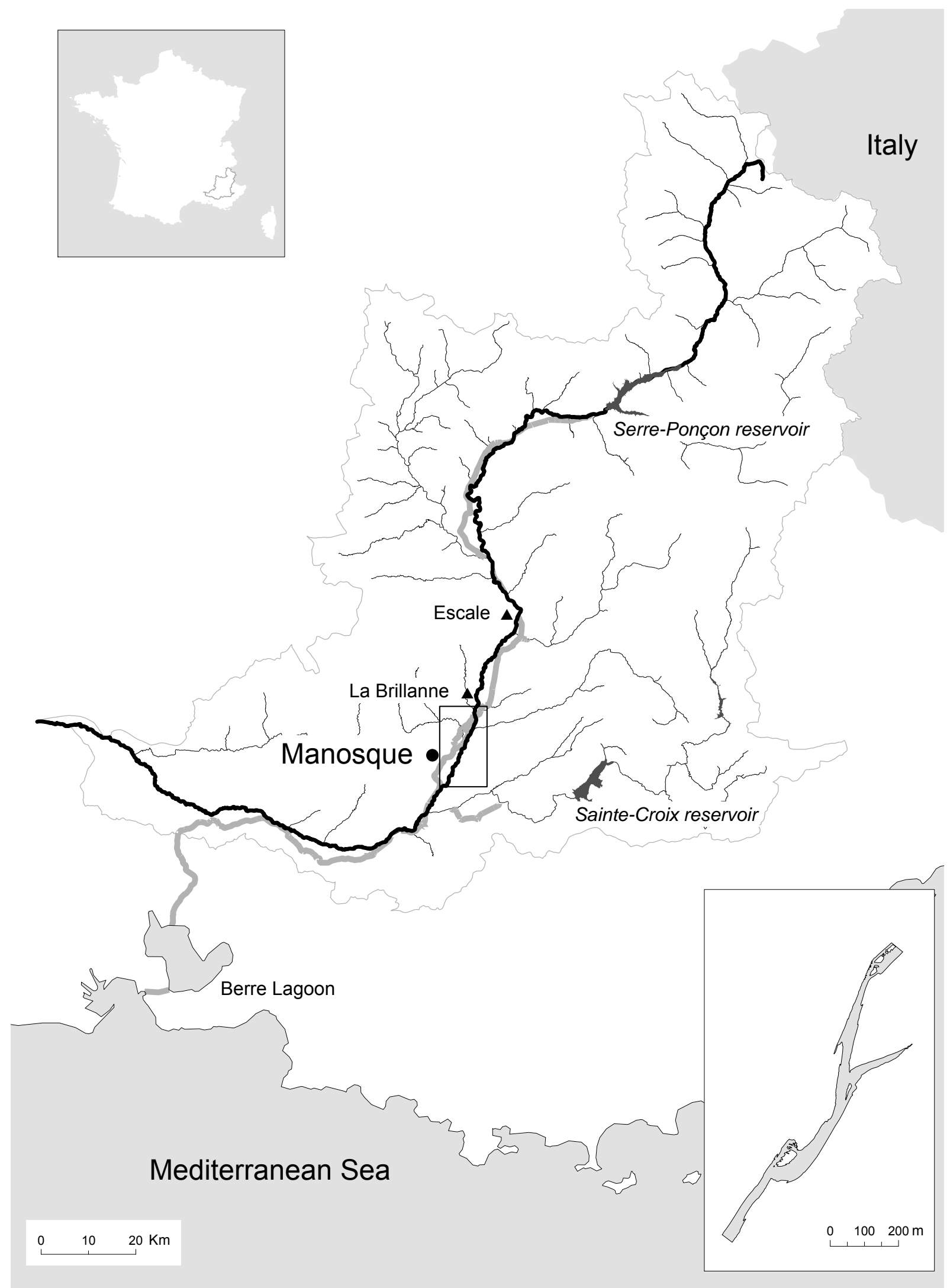

Figure 1: The Durance River basin, its main tributary network (Strahler order $\geq 3$ ) and the study site located near Manosque (Alpes-de-Haute-Provence). A thick grey line outlines the canal supplying 14 hydropower stations from Serre-Ponçon dam to Berre Lagoon. For clarity, all hydropower stations are omitted from the map. Escale and La Brillanne are gauging stations (see Figure 2). The bottom-right insert shows the studied river reach during the two final years, 2004 and 2005. Document sources: U.R. Hydrobiologie - Cemagref Aix-en-Provence, @IGN, BD CARTHAGE® RMC. 


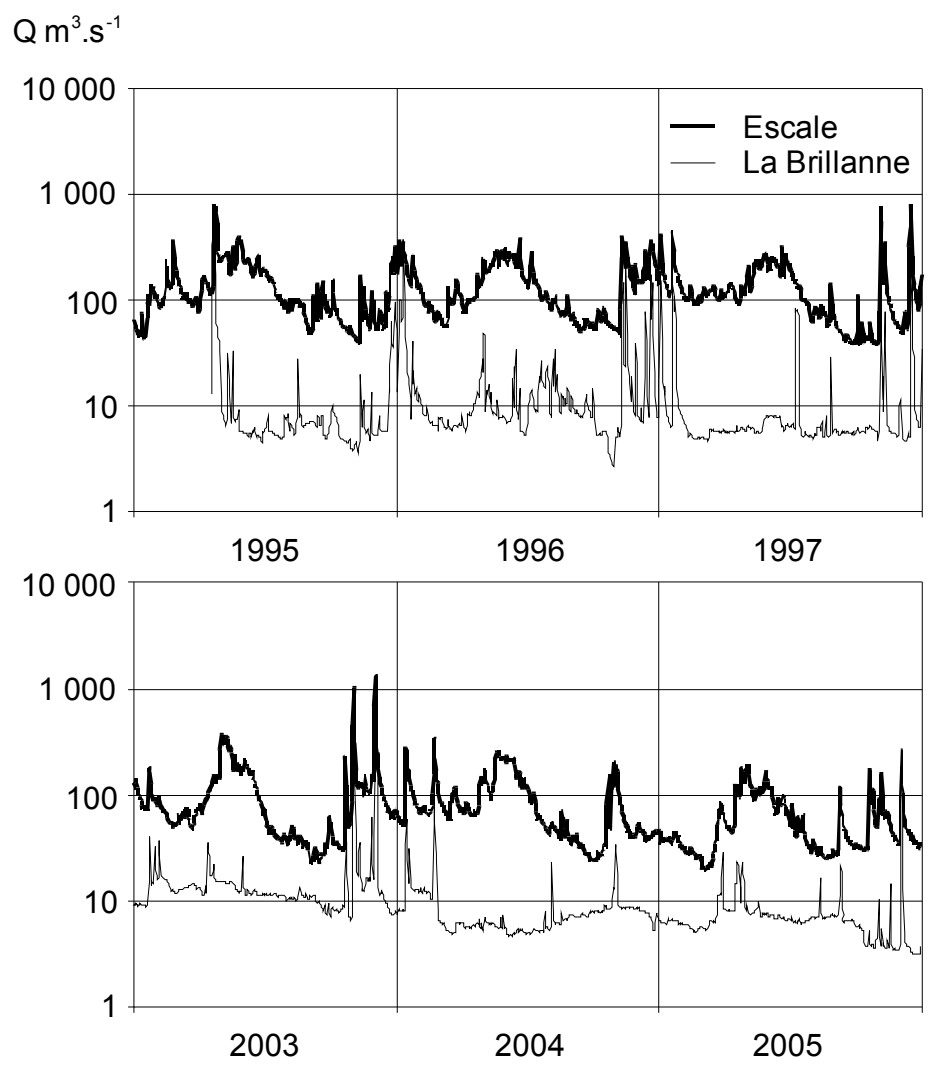

Figure 2 - Time-series of mean daily discharge of the Durance River at Escale and at La Brillanne for the two study periods: 1995-1997 and 2003-2006. At Escale $\left(44^{\circ} 05^{\prime} 11^{\prime \prime} \mathrm{N}, 6^{\circ} 00^{\prime} 45^{\prime \prime} \mathrm{E}\right)$, natural discharge is reconstructed and close to the historical Durance stream flow. At La Brillanne ( $\left.43^{\circ} 56^{\prime} 04^{\prime \prime} \mathrm{N}, 5^{\circ} 53^{\prime} 37^{\prime \prime} \mathrm{E}\right)$, current discharge corresponds to regulated instream flow and includes partial flows from tributaries located between the two gauging stations. Data from the French Hydrology Data Bank HYDRO of the Ministry for Ecology, Sustainable Development and Spatial Planning (http://www.hydro.eaufrance.fr/). 
Table 1 - Main hydromorphological variables of the study site. Mean values were calculated with 1164 transects at $5 \mathrm{~m}$ intervals along the curvilinear axis of the channel. W: width of the channel, dm: mean depth of transect, dM: maximal depth of transect, V: mean velocity and Slope: surface water slope.

\begin{tabular}{lccccc}
\hline & $\mathrm{W}(\mathrm{m})$ & $\mathrm{dm}(\mathrm{m})$ & $\mathrm{dM}(\mathrm{m})$ & $\mathrm{V}\left(\mathrm{m}_{\mathrm{s}} \mathrm{s}^{-1}\right)$ & Slope $(\%)$ \\
\hline Mean & 32.8 & 0.32 & 0.59 & 0.42 & 0.39 \\
Standard deviation & 16.2 & 0.18 & 0.32 & 0.24 & 0.54 \\
Minimum & 7.4 & 0.04 & 0.06 & 0.05 & 0.01 \\
Maximum & 202.5 & 1.11 & 2.05 & 1.85 & 3.05 \\
\hline
\end{tabular}

Table 2 - Variables and their codes obtained by depth (d) and current velocity (v) cross tabulation.

The numerical value of each variable is the percentage area of the cross class in the total area considered. The sum of the 16 variables of the cross table equals $100 \%$. Values are indicated for the whole five year period and for both distinct periods.

depth $(\mathrm{cm})$

\begin{tabular}{|c|c|c|c|c|}
\hline$d>60$ & d4V1 & d4V2 & d4V3 & d4V4 \\
\hline $30<d \leq 60$ & d3V1 & d3V2 & d3V3 & d3V4 \\
\hline $15<d \leq 30$ & d2V1 & d2V2 & d2V3 & d2V4 \\
\hline $0<d \leq 15$ & d1V1 & d1V2 & d1V3 & d1V4 \\
\hline & 0 & -10 & 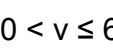 & 60 \\
\hline
\end{tabular}

depth $(\mathrm{cm})$

First period : 1995 to 1997

\begin{tabular}{|c|c|c|c|c|}
\hline$d>60$ & 0.1 & 3.1 & 5.8 & 0.9 \\
\hline $30<d \leq 60$ & 1.6 & 11.9 & 10.8 & 10.6 \\
\hline $15<d \leq 30$ & 1.8 & 9.3 & 11.8 & 5.5 \\
\hline $0<d \leq 15$ & 9.2 & 13.7 & 3.4 & 0.4 \\
\hline & $v \leq$ & $<v \leq 3$ & ) $<\mathrm{v} \leq$ & $v>60$ \\
\hline
\end{tabular}

Total ( 5 year period)

\begin{tabular}{|c|c|c|c|}
\hline 2.3 & 4.5 & 4.6 & 2.1 \\
\hline 2.3 & 9.4 & 10.9 & 11.5 \\
\hline 2.0 & 7.7 & 11.0 & 5.4 \\
\hline 8.6 & 12.9 & 4.3 & 0.4 \\
\hline
\end{tabular}

$0<\mathrm{v} \leq 5 \quad 5<\mathrm{v} \leq 30 \quad 30<\mathrm{v} \leq 60 \quad \mathrm{v}>60 \quad$ Velocity $\left(\mathrm{cm} . \mathrm{s}^{-1}\right)$

Second period : $2004-2005$

\begin{tabular}{|c|c|c|c|}
\hline 4.7 & 6.0 & 3.3 & 3.4 \\
\hline 3.1 & 6.8 & 11.1 & 12.4 \\
\hline 2.3 & 6.0 & 10.2 & 5.2 \\
\hline 7.9 & 12.0 & 5.3 & 0.4 \\
\hline
\end{tabular}

$0<\mathrm{v} \leq 5 \quad 5<\mathrm{v} \leq 30 \quad 30<\mathrm{v} \leq 60 \quad \mathrm{v}>60 \quad \operatorname{Velocity}\left(\mathrm{cm} . \mathrm{s}^{-1}\right)$ 


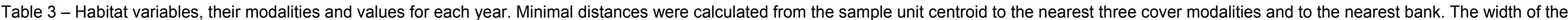

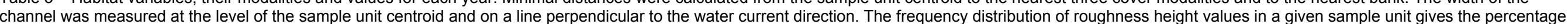
of each size class (variable $\boldsymbol{k}_{\boldsymbol{i}}$ ).

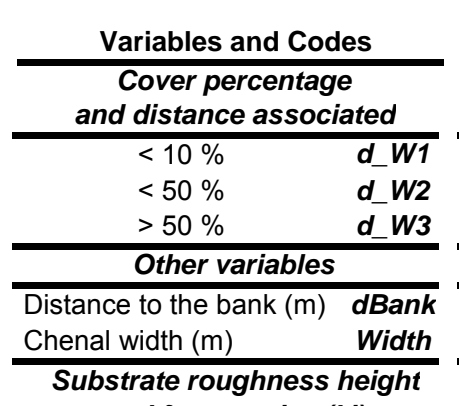

\begin{tabular}{rr}
\multicolumn{2}{c}{1995} \\
\hline Mean $( \pm$ sd $)$ & [Min. - Max.] \\
\hline $\mathbf{2 8 2}( \pm 282)$ & {$[5-861]$} \\
$\mathbf{5 2}( \pm 60)$ & {$[0.1-191]$} \\
$\mathbf{1 3 7}( \pm 183)$ & {$[0.1-574$} \\
\hline & \\
\hline $\mathbf{4}( \pm 4)$ & {$[0.1-21]$} \\
$\mathbf{2 0}( \pm 12)$ & {$[4-48]$} \\
\hline
\end{tabular}

\begin{tabular}{rr}
\hline \multicolumn{2}{c}{1996} \\
\hline Mean $( \pm$ sd $)$ & [Min. - Max.] \\
\hline $\mathbf{8 0}( \pm 96)$ & {$[0.3-348]$} \\
$\mathbf{1 9 1 ( \pm 1 3 6 )}$ & {$[1.2-464]$} \\
$\mathbf{1 0 0 ( \pm 9 0 )}$ & {$[0.1-329]$} \\
\hline & \\
\hline $\mathbf{5 (}( \pm 4)$ & {$[0.3-19]$} \\
$\mathbf{1 8}( \pm 10)$ & {$[3-46]$} \\
\hline
\end{tabular}

\begin{tabular}{|c|c|}
\hline \multicolumn{2}{|c|}{1997} \\
\hline Mean $( \pm s d)$ & [Min. - Max.] \\
\hline $30( \pm 22)$ & $\overline{[0.8-80]}$ \\
\hline $52( \pm 33)$ & {$[2.1-110]$} \\
\hline $46( \pm 37)$ & {$[0.2-113]$} \\
\hline $6( \pm 5)$ & {$[0.4-19]$} \\
\hline $27( \pm 12)$ & {$[4-44]$} \\
\hline
\end{tabular}

\begin{tabular}{|c|c|}
\hline \multicolumn{2}{|c|}{2004} \\
\hline Mean $( \pm s d)$ & [Min. - Max.] \\
\hline $58( \pm 62)$ & {$[0.6-285]$} \\
\hline $48( \pm 53)$ & {$[0.4-226]$} \\
\hline $34( \pm 34)$ & {$[0.01-154]$} \\
\hline $6( \pm 6)$ & {$[0.1-27]$} \\
\hline $25( \pm 12)$ & {$[2-55]$} \\
\hline
\end{tabular}

\begin{tabular}{rr}
\hline \multicolumn{2}{|c}{2005} \\
\hline Mean $( \pm$ sd) & [Min. - Max.] \\
\hline $\mathbf{3 7}( \pm 42)$ & {$[0.1-199]$} \\
$\mathbf{5 3}( \pm 57)$ & {$[0.3-244]$} \\
$\mathbf{3 6}( \pm 33)$ & {$[0.2-155]$} \\
\hline & \\
\hline $\mathbf{6 ( \pm 5 )}$ & {$[0.1-20]$} \\
$\mathbf{2 5 ( \pm 1 1 )}$ & {$[6-50]$} \\
\hline
\end{tabular}

and frequencies ( $k$ i)

\section{and frequend}

$[0.0625-1.6 \mathrm{~cm}$ ]

k1

\begin{tabular}{rr}
\hline $\mathbf{3 . 9}( \pm 16.3)$ & {$[0-100]$} \\
$\mathbf{1 8 . 8}( \pm 22.7)$ & {$[0-93.3]$} \\
$\mathbf{4 7 . 7}( \pm 20.3)$ & {$[0-92.3]$} \\
$\mathbf{2 9 . 3}( \pm 24.5)$ & {$[0-76.9]$}
\end{tabular}

$\begin{array}{rr}\mathbf{8 . 4}( \pm 23.6) & {[0-100]} \\ \mathbf{7 . 9}( \pm 12.1) & {[0-44.4]} \\ \mathbf{4 7 . 1}( \pm 19.7) & {[0-86.6]} \\ \mathbf{3 5 . 9}( \pm 22.9) & {[0-86.6]} \\ \mathbf{0 . 6}( \pm 2.2) & {[0-12.5]}\end{array}$

\begin{tabular}{rr}
\hline $\mathbf{8 . 7}( \pm 25.5)$ & {$[0-100]$} \\
$\mathbf{2 2 . 7}( \pm 20.1)$ & {$[0-76.9]$} \\
$\mathbf{4 4 . 7}( \pm 23.2)$ & {$[0-80]$} \\
$\mathbf{2 3 . 8}( \pm 19.7)$ & {$[0-70]$} \\
$\mathbf{0}( \pm 0)$ & {$[0-0]$}
\end{tabular}

\begin{tabular}{|c|c|}
\hline $6.1( \pm 17.6)$ & {$[0-100]$} \\
\hline $22.3( \pm 21.6)$ & [0 - 78.6] \\
\hline $49.4( \pm 24.3)$ & {$[0-100]$} \\
\hline $17.9( \pm 18.2)$ & {$[0-75]$} \\
\hline $4.2( \pm 14.4)$ & [0 - 78.9] \\
\hline
\end{tabular}

\begin{tabular}{rr}
\hline $\mathbf{2 2 . 7}( \pm 34)$ & {$[0-100]$} \\
$\mathbf{1 4 . 6 ( \pm 1 7 . 2 )}$ & {$[0-64.7]$} \\
$\mathbf{3 9 . 7}( \pm 26.7)$ & {$[0-90]$} \\
$\mathbf{1 9 . 8}( \pm 23.2)$ & {$[0-80]$} \\
$\mathbf{3 . 1}( \pm 12.8)$ & {$[0-90]$}
\end{tabular}

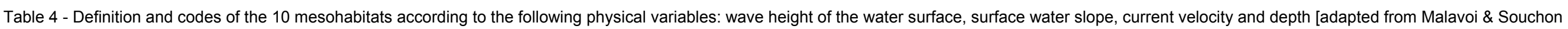
(2002) and Borsany et al. (2004)].

\begin{tabular}{|c|c|c|c|}
\hline Water surface & Slope & Velocity & Depth \\
\hline \multirow{7}{*}{ Waves $<5 \mathrm{~cm}$} & \multirow{3}{*}{$>0.4 \%$} & \multirow{2}{*}{$>30 \mathrm{~cm} \cdot \mathrm{s}^{-1}$} & $>60 \mathrm{~cm}$ \\
\hline & & & $<60 \mathrm{~cm}$ \\
\hline & & $<30 \mathrm{~cm} \cdot \mathrm{s}^{-1}$ & \\
\hline & \multirow{4}{*}{$<0.4 \%$} & \multirow{2}{*}{$>30 \mathrm{~cm} \cdot \mathrm{s}^{-1}$} & $>60 \mathrm{~cm}$ \\
\hline & & & $<60 \mathrm{~cm}$ \\
\hline & & \multirow{2}{*}{$<30 \mathrm{~cm} \cdot \mathrm{s}^{-1}$} & $>60 \mathrm{~cm}$ \\
\hline & & & $<60 \mathrm{~cm}$ \\
\hline \multirow{7}{*}{ Waves $>5 \mathrm{~cm}$} & \multirow{3}{*}{$>0.4 \%$} & \multirow{2}{*}{$>30 \mathrm{~cm} \cdot \mathrm{s}^{-1}$} & $>60 \mathrm{~cm}$ \\
\hline & & & $<60 \mathrm{~cm}$ \\
\hline & & $<30 \mathrm{~cm} \cdot \mathrm{s}^{-1}$ & \\
\hline & \multirow{4}{*}{$<0.4 \%$} & \multirow{2}{*}{$>30 \mathrm{~cm} \cdot \mathrm{s}^{-1}$} & $>60 \mathrm{~cm}$ \\
\hline & & & $<60 \mathrm{~cm}$ \\
\hline & & \multirow{2}{*}{$<30 \mathrm{~cm} \cdot \mathrm{s}^{-1}$} & $>60 \mathrm{~cm}$ \\
\hline & & & $<60 \mathrm{~cm}$ \\
\hline
\end{tabular}




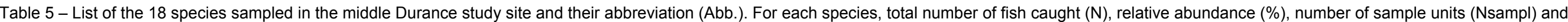

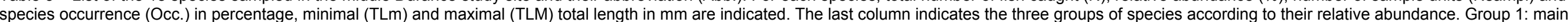
species, $>5 \%$. Group 2: intermediate species, from 1 to $5 \%$. Group 3: rare species, $<1 \%$. Five species were excluded from data analysis: roach, tench, the two salmonids and pumpkinseed.

\begin{tabular}{|c|c|c|c|c|c|c|c|c|c|}
\hline & & Abb. & $\mathrm{N}$ & $\%$ & Nsampl & Occ. & TLm & TLM & Group \\
\hline \multicolumn{10}{|l|}{ Cyprinidae } \\
\hline Leuciscus souffia & Blageon & Lso & 2318 & 19.46 & 191 & 0.66 & 17 & 165 & 1 \\
\hline Alburnoides bipunctatus & Stream bleak & Abi & 2045 & 17.17 & 191 & 0.66 & 11 & 132 & 1 \\
\hline Leuciscus cephalus & Chub & Lce & 1730 & 14.52 & 165 & 0.57 & 17 & 558 & 1 \\
\hline Barbus barbus & Barbel & Bbs & 1463 & 12.28 & 197 & 0.68 & 16 & 610 & 1 \\
\hline Phoxinus phoxinus & Minnow & Pph & 965 & 8.10 & 95 & 0.33 & 14 & 68 & 1 \\
\hline Chondrostoma nasus & Nase & Cna & 520 & 4.36 & 92 & 0.32 & 28 & 525 & 2 \\
\hline Chondrostoma toxostoma & Sofie & Cto & 480 & 4.03 & 89 & 0.31 & 20 & 237 & 2 \\
\hline Gobio gobio & Gudgeon & Ggo & 449 & 3.77 & 104 & 0.36 & 15 & 130 & 2 \\
\hline Alburnus alburnus & Bleak & Aal & 45 & 0.38 & 25 & 0.09 & 18 & 160 & 3 \\
\hline Rutilus rutilus & Roach & Rru & 6 & 0.05 & 5 & 0.02 & 32 & 107 & 3 \\
\hline Tinca tinca & Tench & Tti & 1 & 0.01 & 1 & $<0.01$ & 173 & 173 & 3 \\
\hline \multicolumn{10}{|l|}{ Balitoridae } \\
\hline Barbatula barbatula & Stone loach & $\mathrm{Bba}$ & 1599 & 13.42 & 160 & 0.55 & 22 & 85 & 1 \\
\hline \multicolumn{10}{|l|}{ Cobitidae } \\
\hline Cobitis bilineata & Spined loach & Cbi & 190 & 1.59 & 48 & 0.17 & 31 & 102 & 2 \\
\hline \multicolumn{10}{|l|}{ Percidae } \\
\hline Perca fluviatilis & Perch & $\mathrm{Pfl}$ & 51 & 0.43 & 19 & 0.07 & 66 & 190 & 3 \\
\hline Zingel asper & Rhône streber & Zas & 31 & 0.26 & 20 & 0.07 & 40 & 155 & 3 \\
\hline \multicolumn{10}{|l|}{ Centrarchidae } \\
\hline Lepomis gibbosus & Pumpkinseed & Lgi & 5 & 0.04 & 4 & 0.01 & 85 & 97 & 3 \\
\hline \multicolumn{10}{|l|}{ Salmonidae } \\
\hline Salmo trutta & Brown trout & Str & 12 & 0.10 & 10 & 0.03 & 61 & 240 & 3 \\
\hline Oncorhynchus mykiss & Rainbow trout & Omy & 3 & 0.03 & 2 & 0.01 & 290 & 350 & 3 \\
\hline Total number of fish & & & 913 & & & & & & \\
\hline
\end{tabular}




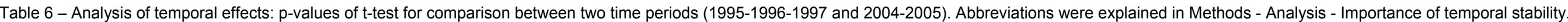

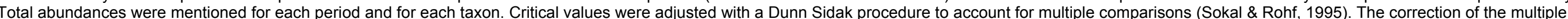

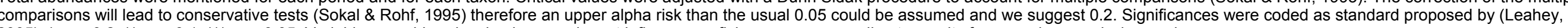
2005): ${ }^{*} p<=0.2,{ }^{* *} p<=0.1,{ }^{* * *} p<=0.05$. Variables considered as having no relevant influence on fish presence according to results from previous analysis are shown as grey.

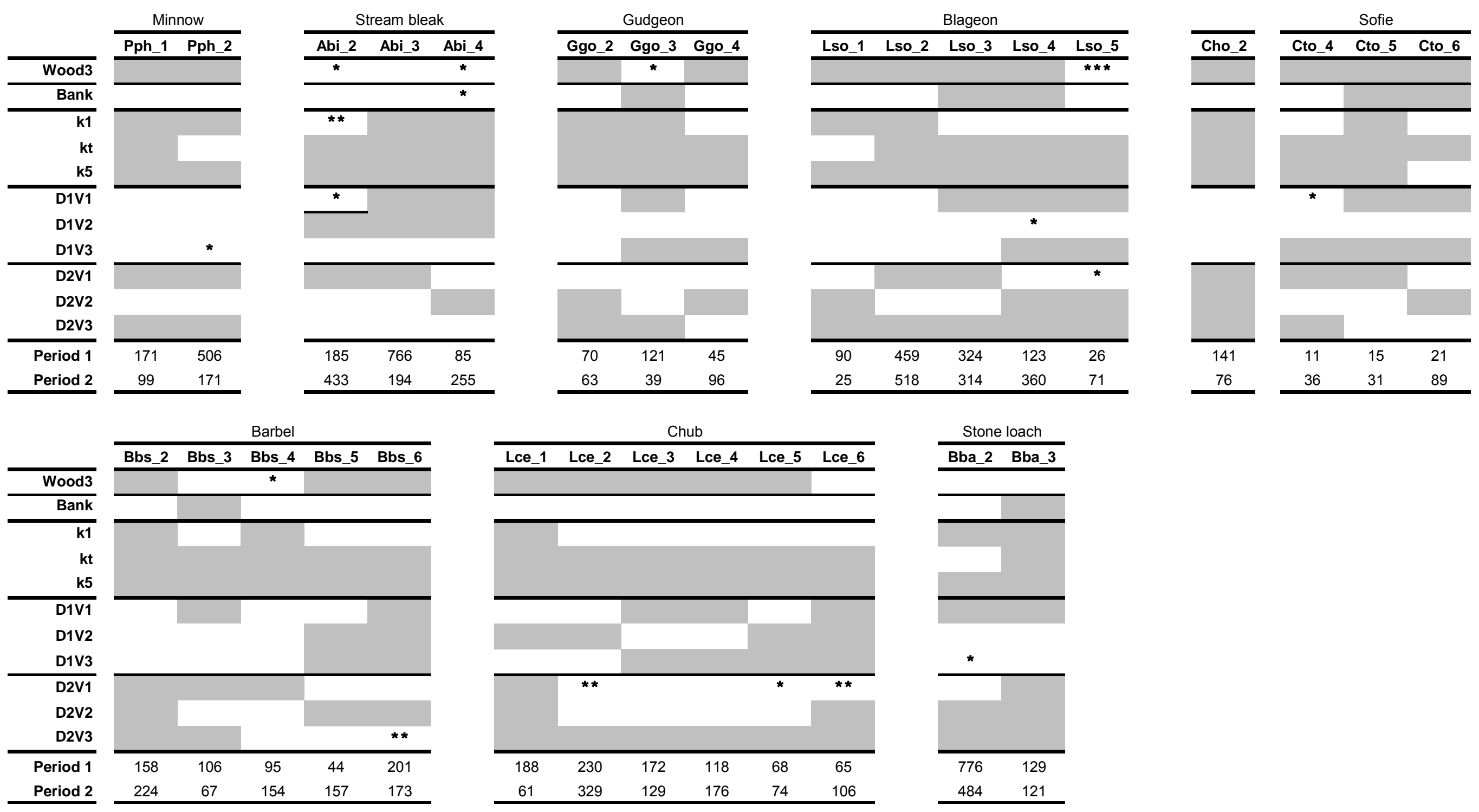




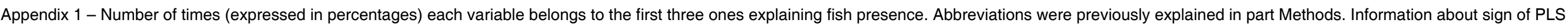

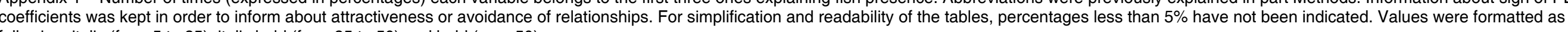
following: italic (from 5 to 25), italic bold (from 25 to 50 ) and bold (over 50)

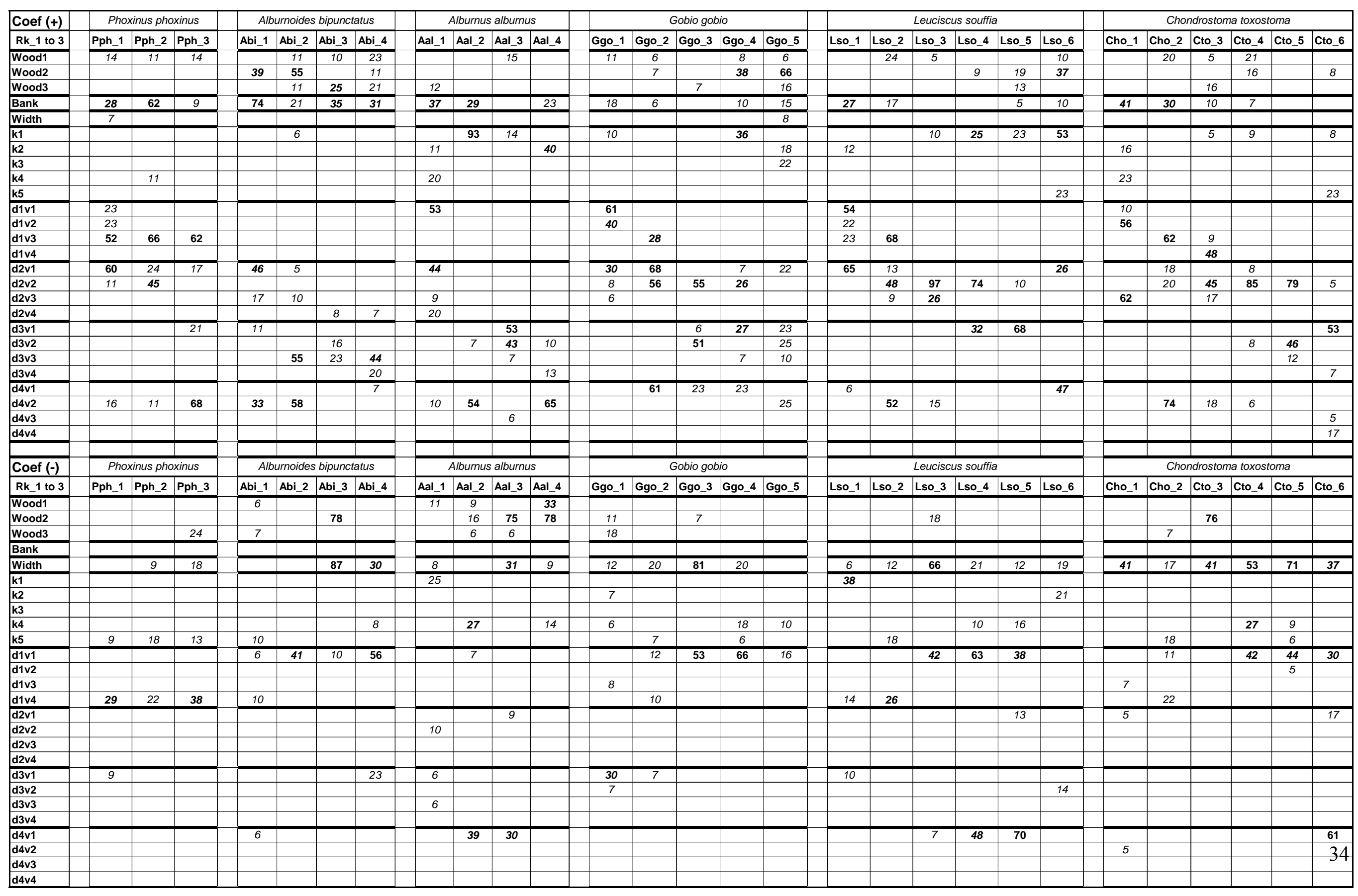




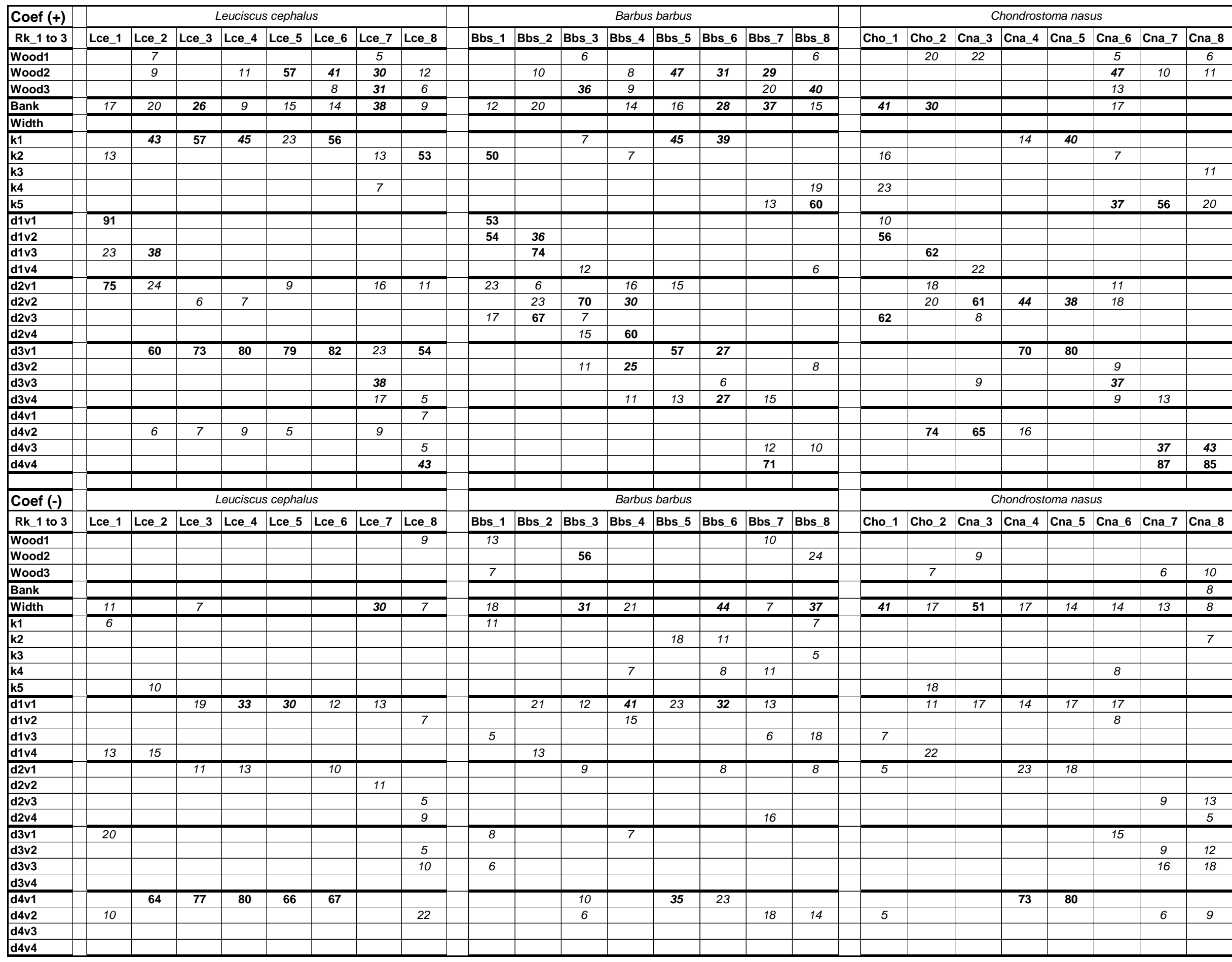




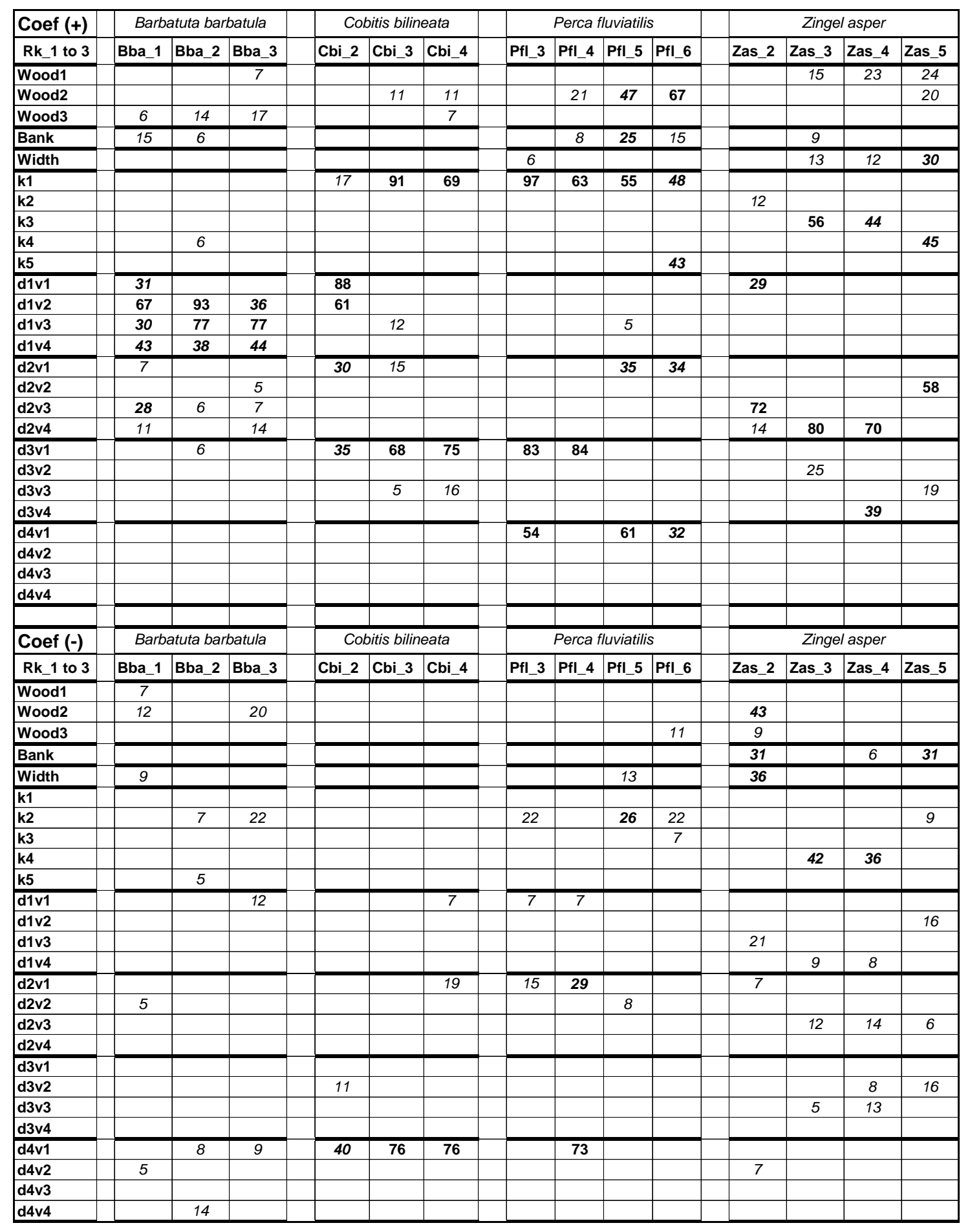

